\title{
What do we know about paddle?
}

\begin{abstract}
The paddle is a sport with great social impact in Spanish speaking countries. It is a physical activity of shovel and ball with a common origin to the rest of the most popular racket sports. It has a great socializing power so it is situated between one of the seven most practiced sports and the fourth with more federative licenses in Spain. Its field with reduced measures $(20 \times 10)$ and that the development of the game is in pairs makes it a relatively easy sport to practice. The objective of this work is to gather information to analyze the characteristics and aspects of this sport. In conclusion, a synthesis of the information obtained is provided.
\end{abstract}

Keywords: Paddle, systematic review, game analysis
Volume I Issue 5 - 2017

\author{
Villena Serrano Manuel,' Zagalaz Sánchez \\ María Luisa, ${ }^{2}$ Castro López Rosario, ${ }^{3}$ Cachón \\ Zagalaz Javier ${ }^{2}$ \\ 'Doctorando del Programa Innovación Didáctica y Formación \\ de Profesorado, Universidad de Jaén, Spain \\ ${ }^{2}$ Facultad de Humanidades y Ciencias de la Educación \\ Universidad de Jaén, Spain \\ ${ }^{3}$ Centro de Magisterio Sagrado Corazón, Universidad de \\ Córdoba, Spain
}

\begin{abstract}
Correspondence: Villena Serrano Manuel, Doctorando del Programa Innovación Didáctica y Formación de Profesorado, Universidad de Jaén, Spain, Tel +34957542049,

Email m_villena_serrano@yahoo.es
\end{abstract}

Received: May 23, 2017 | Published: December 07, 2017

\section{Introduction}

Paddle is a sport of great social recognition in Spanish speaking countries. In Spain, it has become the seventh most practiced according to data from the CIS and the fourth with more federative licenses, with a total of 61,220 athletes. ${ }^{1}$ These data do not agree with the lack of scientific works of this sport, although it is also one of the sports on which the number of players in Spain is increasing. Among others that is due to the socializing power of its practice (before, during and after the game). With respect to the game analysis and the scientific work connected to paddle developed so far, only 54 references have been found. Paddle references have been decanted towards the analysis of sports performance, especially of the game, technique and Tactics, with very little work being done in the rest of thematic areas ${ }^{2}$ (Figure $1)$.

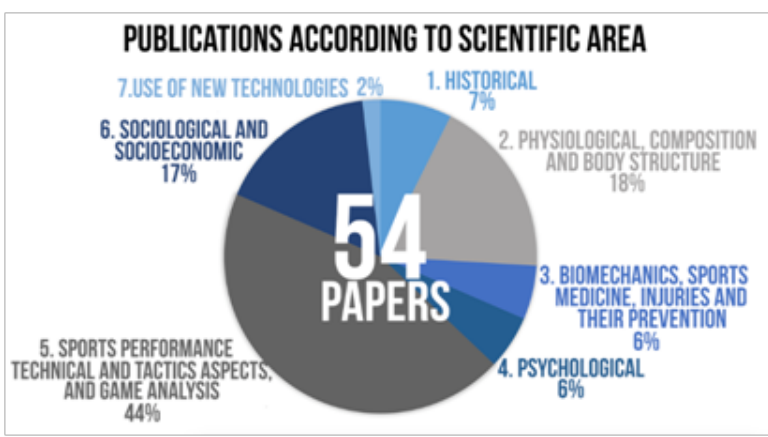

Figure I Analysis of papers by scientific areas.

For this reason it is opportune to investigate the historical, physiological, biomechanical, psychological, sports performance, sociological aspects and use of information and communication technologies (ICT) related to the paddle to have a more detailed knowledge about this sport.

\section{Discussion}

For the analysis of the different aspects of this sport, 7 thematic areas have been established.

\section{Historical area}

It is a relatively young sport, devised by Enrique Corcuera in 1962 in Mexico City, ${ }^{3}$ which in 1974 was introduced in Spain by Alfonso de Hogenlohe. ${ }^{4}$ Its origins, in the middle Ages in France (jeu de paume), ${ }^{5}$ are related to the background of the rest of racket sports with more tradition. ${ }^{6}$ The field of play is a rectangle of $20 \times 10$ divided in its half by a net. In each field can be observed (Figure 2) the service lines (parallel to the net) and perpendicular to the central service line. ${ }^{7}$ The track is completely closed, as shown in Figure 3. In the enclosure we can find materials that allow the natural bounce of the ball and metal areas where the rebound is irregular. ${ }^{7}$ Finally, the material for the development of this sport practice is specific, that is to say, the blades and balls have certain characteristics (Figure 4).

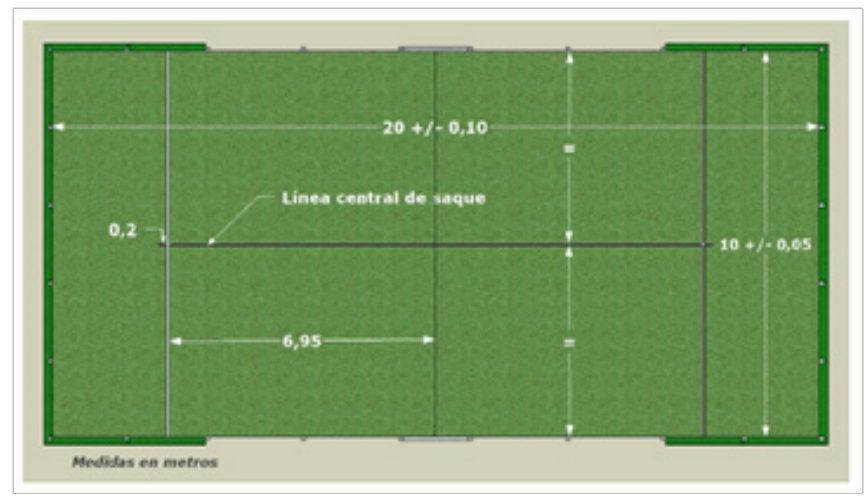

Figure 2 Measures Paddle court.

\section{Physiological composition and body structure}

These works are intended to provide useful information for sports performance. As the most relevant results, the male paddle player has a mesoendomorphic and female endomesomorphic profile. ${ }^{8}$ It is an intermittent acyclic sport, the most important metabolic pathway is aerobic ${ }^{9}$ and $82 \%$ and $93 \%$ of the maximum HR. ${ }^{8}$ Finally, Bartolomé et al. ${ }^{10}$ have analyzed the amount of concentration of minerals in the urine to determine the internal load of this sport. As a most relevant 
result, these authors have found low levels of Lithium (Li) in the concentration of urine after a match of paddle, this being an essential mineral since it is related to the energy metabolism and the regulation of the adequate function of several biological systems Bartolomé et al. ${ }^{10}$

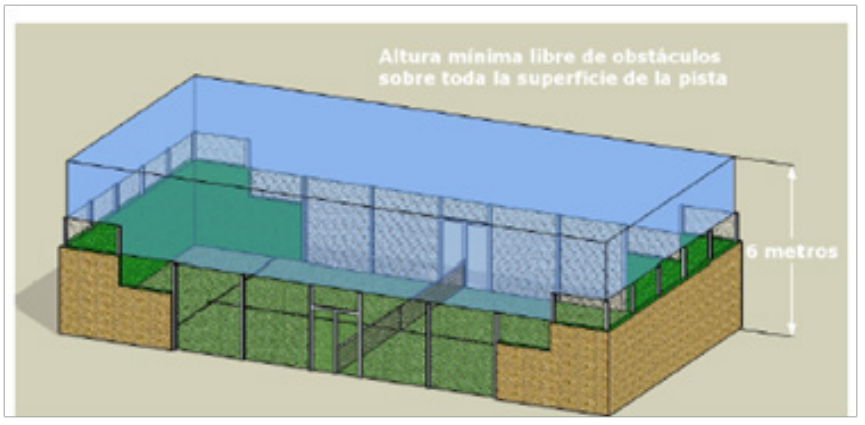

Figure 3 Enclosure Pádel track.

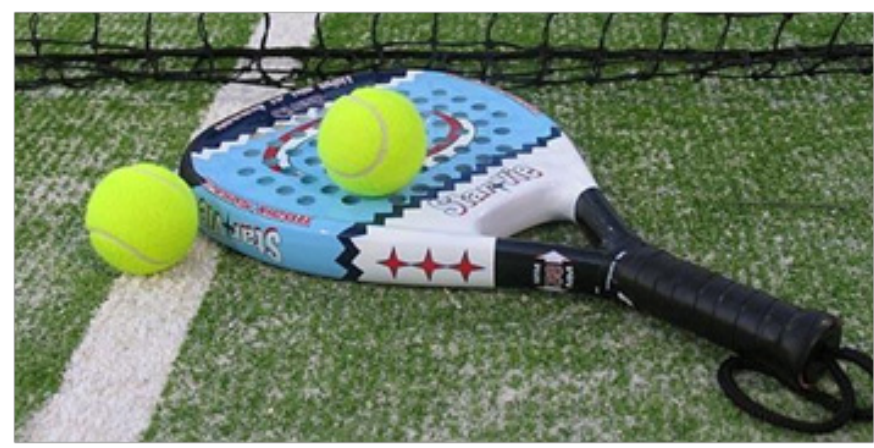

Figure 4 Ball and paddle shovel.

\section{Biomechanical area, sports medicine, injuries and prevention}

Mainly, these works are developed to prevent and avoid injuries that are to prevent interruption of training-competition. The most common injuries in the paddle are ankle sprain, twin rupture and ligamentous knee injuries. ${ }^{11}$

\section{Psychological}

The level of activation, self-esteem, stress, anxiety can modify the performance of the athlete in any sports modality; in addition they are aspects that have been analysed in the paddle. ${ }^{12}$ On the other hand, psychological factors have been studied in relation to sports injuries. ${ }^{13}$

\section{Area of sports performance, technical, tactical, didactic aspects and analysis of the game}

The paddle is a sport that owns technical gestures and a determined tactic. For the teaching of technique, the analytical method is the most used for performance improvement. ${ }^{14}$ In the paddle, as open sports with a changing environment, tactics play an important role within the demands of the game. ${ }^{2}$ For the analysis of the game, the studies have analysed the most frequent beatings in the competition ${ }^{15}$ which are the auction and the deep and crossed balloon. Another aspect to analyse is the temporal structure in which all authors conclude that it is an intermittent sport where rest time is higher than that of play. ${ }^{16,17}$

\section{Sociological and socioeconomic}

The association between physical activity and health is indisputable, in the case of the paddle it is reinforced by having a high recreational level, the fun and the values that it entails, ${ }^{18}$ such as the promotion of friendships, affirmation of self-esteem and participation of children and men and women of different ages, which also makes it an innovative educational tool.

\section{Use of new technologies}

The uses of new technologies are common. The video allows knowing aspects of the game that in situ the player does not appreciate it. Its use is mainly for the analysis of the technique or keeps a record of any parameter that can be studied. ${ }^{19}$

\section{Conclusion}

In this work the main aspects of the paddle have been analysed and information has been collected on the most analysed thematic areas of this sport. As a conclusion, it is stated that it is a fairly young sport both because of the physical activity it represents and because of the few analyses or related investigations (54 jobs), which is striking in comparison with the high number of players in Spain. The most studied area is the Sports performance, technique, tactics, didactics and game analysis and highlights the lack of work related to the rest of thematic areas. As a limiting factor is again observed the lack of paddle work in the Anglo-Saxon world, this may be due to the fact that the practice of this sport is almost exclusive in Spanish-speaking countries, perhaps due to climatological issues considered in its beginnings. ${ }^{20,21}$ As future prospects, it is proposed to deepen the study of this sport in Spanish-speaking countries as well as in other languages, in addition to specifying its scientific bases and to influence the development of scientific studies where parameters not yet studied are analysed. ${ }^{22,23}$

\section{Acknowledgements}

The research leading to the writing of this paper has been funded by the Andalusian Plan for Research, Development and Innovation (PAIDI) Research Group HUM653, Educational Innovation in Physical Exercise (IDAF) and by the Doctoral Programme in Educational Innovation and Teacher Training, both attached to the University of Jaén.

\section{Conflict of interest}

The authors declare that they have no competing interest.

\section{References}

1. Federación Española de Pádel. Datos de jugadores federados. Recuperado el 12-5-2017 en, FEP. Spain; 2007.

2. Serrano VM, López CR, Sánchez LA, et al. Revisión sistemática de las características e incidencia del pádel en España. Estado del Arte Apunts EF y Deportes. 2016;126(4):7-22.

3. Castro R, Cachón J, Valdivia P, et al. History of Paddle. 14th ITTF Sports Science Congress, 5th World Racquet Sports Congress, China; 2015.

4. Castaño J. Iniciación al pádel. Wanceulen, Spain; 2009. p. 166.

5. Cruz AB. Perfil de juego en pádel de alto nivel. Universidad de Jaén, Spain; 2011.

6. Lasaga MJ. Estudio social y metodológico del pádel desde la precepción de técnicos y jugadores: Una apuesta educativa. Departamento de educación física y deportes, Universidad de Sevilla, Spain; 2010.

7. Federación Española de Pádel. Asamblea general federación internacional de pádel. Reglamento de Juego, Spain; 2010. 
8. Pradas F, Cachón J, Otín D, et al. Análisis antropométrico, fisiológico y temporal en jugadoras de pádel de elite. Retos Nuevas tendencias en educación fisica, deporte y recreación. 2014;25:107-112.

9. Amieba C, Salinero JJ. Aspectos generales de la competición del pádel y sus demandas fisiológicas. AGON International Journal of Sport Sciences. 2013;3(2):60-67.

10. Bartolomé I, Córdoba L, Crespo C, et al. Effects of a paddle match on the urinary excretion of trace minerals in high-level players. Science \& Sports. 2016;31(5):e131-e137.

11. Prado DF, Alcaraz SBJ, Navarro GJN, et al. Prevención de lesiones en pádel. Trances. 2013;6(4):175-188.

12. Barquín RR, García LO. Características psicológicas en los jugadores de pádel de alto rendimiento. Revista Iberoamericana de Psicología del Ejercicio y el Deporte. 2008;3(2):183-199.

13. Olmedilla A, Ortega E, Abenza L, et al. Lesiones deportivas y psicología: una revisión (2000-2009). Cuadernos de Psicología del Deporte. 2011;11(1):45-57.

14. Lees A. Technique analysis in sports: a critical review. J Sports Sci. 2002;20(10):813-828.

15. Carrasco L, Romero S, Sañudo B, et al. Game analysis and energy requirements of paddle tennis competition. Science \& Sports. 2011;26(6):338-344.
16. Alcaraz SBJ. Diferencias en las acciones de juego y la estructura temporal entre el pádel masculino y femenino profesional. Acción Motriz. 2014;12:17-22.

17. Sañudo B, Hoyo DM, Carrasco L. Demandas fisiológicas y características estructurales de la competición del pádel masculino. Apunts. EF y Deportes. 2008;94(4):23-28.

18. Cachón J. Entusiasmo, delirio, deporte, fervor, pasión, PÁDEL? Journal of Sport and Health Research. 2014;6(1):3-6.

19. Fernández J, Martín JC. Análisis técnico y táctico del remate del globo en 8 jugadores profesionales de pádel. León: Universidad de León, Spain; 2014.

20. Serrano VM, Sánchez ZML, Zagalaz CJ, et al. II Congreso Internacional en Investigación y Didáctica de la Educación Física. El pádel De las pistas al papel. Spain; 2017.

21. Serrano VM, Sánchez ZML, López CR, et al. El pádel Revisión sistemática de la base de datos TESEO. Sportis Sci J. 2017;3(2):287-375.

22. Centro de Investigaciones Sociológicas. Estudio n ${ }^{\circ} 3029$. Barómetro de junio 2014, CIS. Spain; 2014.

23. Periodistadigital. Las diez mejores palas de pádel en calidad y precio. Recuperado el 12-5-2017 en, Spain; 2011. 